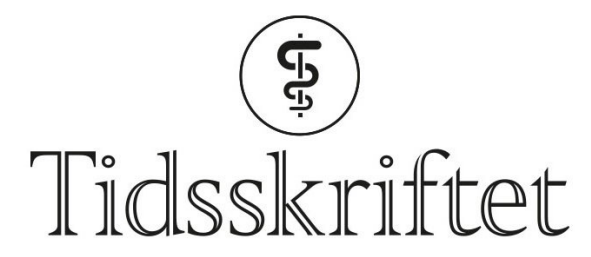

DEN NORSKE LEGEFORENING

\title{
Blodtrykksbehandling i lavinntektsland
}

FRA ANDRE TIDSSKRIFTER

KRISTOFFER BRODWALL

Barne- og ungdomsklinikken Haukeland universitetssykehus

Tett oppfølging fra primærhelsetjenesten bedrer effekten av blodtrykkssenkende behandling i lavinntektsland.

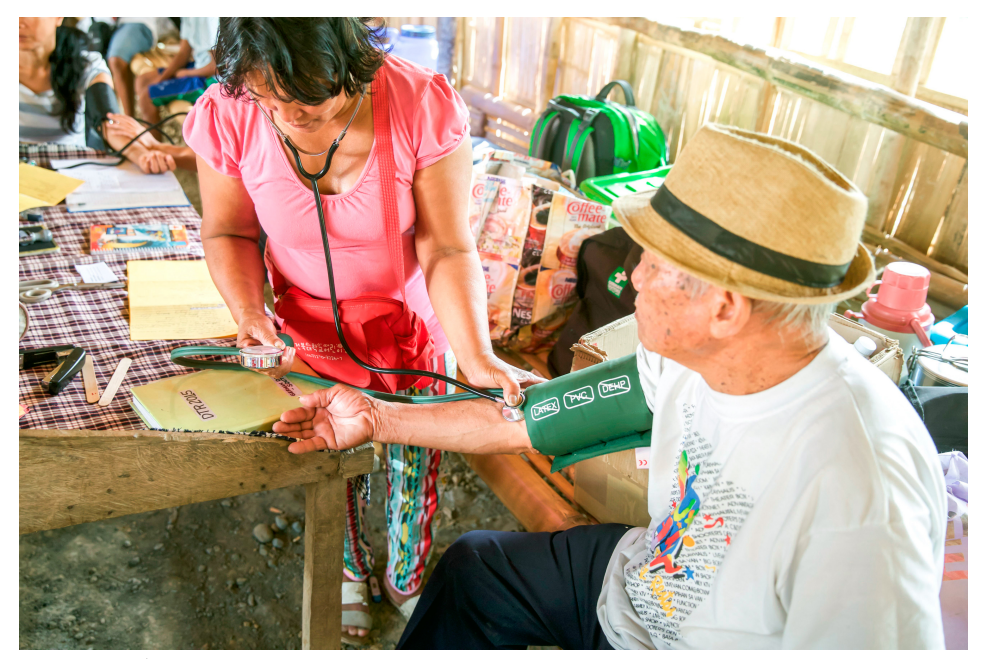

Foto: DPA

Høyt blodtrykk er en viktig årsak til hjerte- og karsykdom. Det er beregnet at rundt en tredel av alle voksne personer i verden har høyt blodtrykk, og av disse lever $75 \%$ i lav- og mellominntektsland, hvorav færre enn en tidel lykkes i å senke blodtrykket til mindre enn 140/9o mm Hg. Det er derfor behov for flere effektive tiltak for å bedre blodtrykksbehandlingen i lav- og mellominntektsland.

I en fersk studie fra Argentina ble effekten av en kombinasjon av flere tiltak for å gi bedre blodtrykksbehandling unders $ø$ kt (1). Ni primærhelsesentre med 689 pasienter ble randomisert til standard behandling, mens ni sentre med 743 pasienter ble randomisert til en pakke med forskjellige intervensjoner: Utdeling av automatiske blodtrykksmålere og tablettdosetter til pasientene samt veiledning i livsstilsendringer og om riktig bruk av blodtrykkssenkende medisiner for pasienter og deres familiemedlemmer. Helsearbeidere i intervensjonsgruppen fikk relevant etterutdanning, og de reiste på månedlige hjemmebesøk til pasientene det første halvåret, deretter annenhver måned.

Etter 18 måneder var systolisk blodtrykk redusert med gjennomsnittlig 19,3 mm Hg i 
intervensjonsgruppen, mot 12,7 mm Hg i kontrollgruppen ( $\mathrm{p}<\mathrm{o}, \mathrm{oo1}$ ). Reduksjonen for diastolisk blodtrykk var henholdsvis $12,2 \mathrm{~mm} \mathrm{Hg} \mathrm{og} \mathrm{6,9} \mathrm{mm} \mathrm{Hg}(\mathrm{p}<0,001)$. Langt flere oppnådde velkontrollert blodtrykk i intervensjonsgruppen enn i kontrollgruppen (73\% $\operatorname{mot} 52 \%$ ).

Studien tyder på at programmet var effektivt, men det er uklart hvilke deler av intervensjonen som bidro til effekten. Kostnad-nytte-effekten er heller ikke unders $ø$ kt.

\section{LITTERATUR:}

1. He J, Irazola V, Mills KT et al. Effect of a Community Health Worker-Led Multicomponent Intervention on Blood Pressure Control in Low-Income Patients in Argentina: A Randomized Clinical Trial. JAMA 2017; 318: 1016 - 25. [PubMed][CrossRef]

Publisert: 13. november 2017. Tidsskr Nor Legeforen. DOI: 10.4045/tidsskr.17.0859

(C) Tidsskrift for Den norske legeforening 2020. Lastet ned fra tidsskriftet.no 